\title{
Od Fantazji do Gumballa - estetyka filmu animowanego
}

\section{From Fantasia to Gumball - the Aesthetics of the Animated Film}

\author{
Katarzyna Mąka-Malatyńska \\ Uniwersytet im. Adama Mickiewicza
}

\begin{abstract}
The paper attempts to answer, what was the animation in the past and what it is today. According to the author animated film stands out a special references with the physical reality, a creativity and a syncretism. She describes two trends in animated film: the art animation and the popular animation and she analyzes two examples meeting this trends: Walt Disney's Fantasia and contemporary TV series such as The Amazing World of Gumball.
\end{abstract}

Key words: animation, cartoons, film for children, animated series, the aesthetics of the film, film genre, The Amazing World of Gumball .

Streszczenie: Artykuł stanowi próbę odpowiedzi na pytanie, czym była animacja niegdyś i czym jest dziś. Na podstawie refleksji filmoznawców i twórców autorka formułuje definicję filmu animowanego, wskazując na ograniczenie referencjalności, fikcjonalność i charakter synkretyczny jako główne wyróżniki filmu animowanego. Przywołuje dwa nurty działalności twórców animacji: film artystyczny i film masowy, popularny oraz omawia dwa przykłady ich krzyżowania się: słynną Disneyowską Fantazję oraz wybrane współczesne seriale dla dzieci.

Słowa kluczowe: film animowany, film dla dzieci, serial animowany, estetyka filmu, genologia filmu, Niesamowity świat Gumballa.

\section{Tam, gdzie kończy się imitacja, zaczyna się animacja}

W refleksji filmoznawczej zwykło się przyjmować podział na dwa rodzaje filmowe: fiction i non-fiction. Film animowany dość rzadko analizowany bywa w perspektywie genologicznej. Rozważa się go zwykle na uboczu przywołanego podziału, jako swoisty trzeci rodzaj, o czym najlepiej świadczą podręczniki historii kina, w których osobno omawia się film fabularny, osobno dokumentalny i osobno, jeśli w ogóle, animowany. Tymczasem animacja bez wątpienia należy do fikcjonalnej gałęzi filmu. Według Paula 
Wellsa „posługuje się odrębnym językiem, pozwalającym tworzyć sztukę niemożliwości, gdzie wszystko, co wyobrażalne jest zarazem osiągalne" (Wells 2009, 11). Głównym wyróżnikiem filmu animowanego wydaje się jego niewielka referencjalność. Wells podkreśla także, że animacja daje większe niż film aktorski, możliwości kontrolowania procesu twórczego, może być osadzona w świecie fizycznym (np. lalki), ale „może też rzeczywistość imitować lub tworzyć nowe światy, rządzące się zupełnie innymi prawami niż świat rzeczywisty" (Wells 2009, 12). Taką refleksję znajdujemy w pracach wielu teoretyków, między innymi Béli Balázsa:

Świat animacji to świat zamknięty, w którym królują inne formy niż w naszym świecie rzeczywistym. (...) Przygody form, które ożyły, mają swoją surową logikę. Przyczynę i skutek wyznaczają tu nie prawa natury, lecz prawa formy. Jeśli jeden $\mathrm{z}$ bohaterów filmu zaatakuje drugiego pędzlem i namaluje mu garb, to tamten pozostaje na zawsze garbatym (Balázs 1957, 182).

$\mathrm{Na}$ niezwykłą siłę animacji zwracał uwagę jeden z pionierów polskiej refleksji nad filmem, Karol Irzykowski. W X Muzie, wydanej w roku 1924, pisał:

Gdy przyszłość filmu zwykłego należy do inżynierów materii (ciała ludzkiego i ciała przyrody), to przyszłość filmu rysunkowego należy do malarza-poety. I właściwie jedynie tego filmu możliwość poręcza kinu charakter sztuki (Irzykowski 1982, 258).

Wszelkie próby sformułowania definicji filmu animowanego czy animacji kończyły się niepowodzeniem. A jednak podejmowane były wciąż od nowa przez teoretyków, ale i przez twórców oraz - ze względów czysto praktycznych - przez producentów, dystrybutorów i organizatorów festiwali i przeglądów. Najtrwalsze okazują się objaśnienia najbardziej ogólne, a jednocześnie, niestety, najmniej mówiące o istocie animowanej twórczości filmowej. W latach 80. Association Internationale du Film d'Animation (ASIFA) podało definicję sztuki animacji, czyniąc tym samym film animowany drugim, obok dokumentu, obszarem działalności filmowej, który doczekał się określenia urzędowego. Zgodnie z nią sztuka animacji jest kreacją ruchomych obrazów przy użyciu różnorodnych technik z wyjątkiem metod rejestracji akcji „na żywo” (Denslow 2011). Zasadniczą jej wadą jest ograniczenie przedmiotu do działalności artystycznej i wykluczenie produkcji seryjnej filmów określanych potocznie jako komercyjne, jak choćby animowane reklamy. Jest ona ponadto na tyle szeroka, że mieści w sobie filmy, których nie zwykliśmy określać jako animowane, np. filmy ze zdjęć.

Definicja animacji budzi spory nie tylko wśród teoretyków, ale i pośród autorów filmowych. Niemal każdy z nich nieco inaczej rozumie animację, inaczej rozkłada akcenty. W wielu definicjach dawniejszych i współczesnych przewijają się jednak podobne wątki. Za konstytutywne elementy filmu animowanego uważa się zwykle: ruch, iluzję ruchu, kreacyjność, jego synkretyczny charakter oraz związek z muzyką i plastyką. Jeden z najważniejszych autorów polskiego kina animowanego, Piotr Dumała, zauważa: 
Animator to ktoś pokrewny alchemikom, wynalazcom, badaczom natury, pasjonatom próbującym zbudować perpetuum mobile, poszukującym nieznanego księżyca, nieodkrytego pierwiastka, nowego źródła energii (Dumała 2003, 19).

Kreacyjny charakter filmowej animacji podkreślali również w swej deklaracji twórcy szkoły zagrzebskiej: „Animacja jest technicznym procesem, w którym ostateczny rezultat musi być zawsze kreacyjny. Animować: obdarzać życiem i duszą rysunek, lecz nie za pomocą kopiowania natury, ale poprzez jej transformację" (Sitkiewicz 2013, 13). Część filmowców wskazuje na ruch i iluzję jako istotę kina animowanego. Jeden z czołowych polskich operatorów filmowych, Jerzy Wójcik, pisał: „Pojęcie animacji możemy określić jako ożywienie tego, co nie jest żywe, jako nadanie ruchu” (Wójcik 1997-1998, 57). Współczesna estetyka filmu ujmuje animację nie jako sztukę rysunku, który się wprawia w ruch, ale umiejętność, sztukę wyrażania ruchu przez rysunek lub wycinankę (Wójcik 1997-1998, 58). Młody polski twórca, Wojciech Bąkowski, autor filmu Idziesz ze mna, zwraca uwagę, że ruch w animacji zawsze ma charakter iluzoryczny:

Można wprowadzić założenie, że animacja musi mieć osiem, sześć czy dwadzieścia cztery klatki na sekundę, ale jest to bez sensu. Jeżeli fazy następują jedna po drugiej i rzeczywiście przedstawiają ruch, wówczas jest to film animowany (Frukacz 2008, 43).

Małgorzata Bosek, pytana o możliwość zrealizowania animowanego Dokumanimo w formie dokumentalnej, odpowiada: „Animacja pozwala na wniesienie do filmu własnej, osobistej plastyki, która jest nieodzownym, jednym z najważniejszych elementów w filmie animowanym" (Frukacz 2008, 63). Jej zdaniem zatem to plastyka stanowi wyróżnik animacji i główny środek artystycznej ekspresji. W definicji Wojtka Wawszczyka odnajdujemy oba elementy: ruch i narrację. Pierwszy z nich interesuje twórce jako animatora. Fascynuje go rozpracowywanie mechaniki ruchu, wynikającego z niego rytmu. Jako reżysera filmów animowanych zajmuje go przede wszystkim opowiadanie historii, dla których medium staje się film animowany z jego szczególną plastyką: „Wynika to z moich doświadczeń zakorzenionych w świecie komiksu, który jest opowieścią poprowadzoną za pomocą obrazów. Jestem w większym stopniu gawędziarzem, mniej malarzem, czego często żałuję." (Frukacz 2008, 215-216). W wypowiedzi młodego twórcy Jeża Jerzego pojawia się więc trzeci ważny, choć nie konstytutywny, element filmu animowanego: opowieść, historia. Podsumowanie myślenia o animacji jako połączeniu różnych sztuk znajdujemy w pracach Pawła Sitkiewicza:

Film animowany jest sztuką synkretyczną, czerpiącą z bogactwa przynajmniej kilku języków artystycznych. Synkretyzm animacji, wbrew powszechnemu wyobrażeniu, wybiega daleko poza jej związki z kinem aktorskim i plastyką (Sitkiewicz 2009, 16-17). 
Pokrewieństwo to może, zdaniem autora, obejmować plakat, grafikę, komiks, malarstwo, fotografię, rzeźbę, teatr marionetkowy, muzykę, performance.

Przyglądając się definicjom filmu animowanego, warto pamiętać, że mają one charakter historycznie zmienny i zależny od uwarunkowań kulturowych, w których rodziła się animacja w poszczególnych krajach. W znacznym stopniu zależy ona bowiem od związków z literaturą, komiksem, grafiką, malarstwem, teatrem określonego czasu i miejsca. Kino animowane wchłania bowiem w sposób znaczący i znaczeniotwórczy istotną część tradycji plastycznej, literackiej, teatralnej danej części świata. W historii polskiego autorskiego filmu animowanego bez trudu wskazać możemy na szczególnie bliską relację animacji z malarstwem i ze sztuką plakatu. W tym samym czasie, gdy polski film animowany zyskiwał rangę sztuki (w połowie lat 50. XX wieku), pozostając w ścisłej relacji z grafiką i malarstwem, w Czechosłowacji wyrastał z tradycji teatru marionetkowego. W Stanach Zjednoczonych powstawał z kolei z inspiracji stripami gazetowymi. Dla wielu twórców stanowił po prostu nowe medium opowiadania o funkcjonujących już w zbiorowej świadomości postaciach, jak np. Marynarz Popeye. Nie zawsze też filmy, które dziś są dla nas bezsprzecznie animowane, były za takie uważane w momencie ich powstawania. Najlepszym przykładem jest The Sinking of the Lusitania, krótki film animowany Winsora McCoya z 1918 roku, który dla widzów stał się dokumentalnym obrazem zdarzeń, niezarejestrowanych nigdy dokumentalną kamerą. W 1953 roku Oscara w kategorii krótkometrażowego filmu dokumentalnego otrzymał Norman McLaren za Neighbours, który dziś odczytujemy jako dzieło animacji poklatkowej z udziałem żywego aktora. Zdefiniowanie filmu animowanego raz na zawsze wydaje się więc niemożliwe, jeśli uznamy go za pewną konwencję wypowiedzeniową.

Historia rozumienia pojęcia „film animowany” i „animacja” w pewnym sensie zatoczyła koło. Na przełomie XIX i XX wieku słowem animacja określano film w ogóle, pojmowany wówczas jako ożywiona fotografia. W kolejnych dekadach, gdy animacja zyskiwała rangę sztuki, podkreślano jej odrębność względem innych dziedzin kina. Z czasem stała się również potężną gałęzią przemysłu kinematograficznego. Współcześnie ponownie następuje rozszerzenie definicji. Wyrasta ono jednak z innego podłoża, które można by określić jako „rewolucję cyfrową”, oraz z pewnych nurtów filozofii, przede wszystkim refleksji Jacquesa Derridy. Thomas Elsaesser, w rozważaniach o kinie cyfrowym, przywołuje koncepcje Lwa Manovicha:

Odwrócenie priorytetu czyni z animacji główną, wyższego rzędu kategorię kina, dzięki wszechstronnym możliwościom trybu graficznego, zwłaszcza jeśli dodać do tego grafiki komputerowe, środowiska symulowane i inne rodzaje przestrzeni wirtualnej (Elsaesser 2001, 61). 


\section{Alan Cholodenko pisze:}

Wszelako, choć animacja była marginalizowana przez dyskurs filmoznawczy, zgodnie z logiką parergonu, film może się określić jako film tylko przez animację. Animacja jest tym, co zostało z filmu starte, tym, co usiłuje zataić to zatarcie, i tym, co pozwala filmowi być filmem (Cholodenko 1997-1998, 68).

Animacja z pewnością nie musi być sztuką, nie musi być nawet filmem. Pełni często funkcję służebną wobec innych utworów filmowych. Jest dziś wszechobecna, choć nie zawsze zdajemy sobie z tego sprawę. „Jeżeli lata 40. i 50. XX wieku określano jako złoty wiek animacji, to obecny czas musi być wiekiem platynowym" (Wellins 2015, 10). Obcujemy z nią w filmie aktorskim, w którym korzysta się zwykle z efektów specjalnych, na potrzeby kina tworzone są postaci $\mathrm{w}$ technice motion capture, jak choćby kłapouchy, sympatyczny fajtłapa Jar Jar Binks z I i II epizodu Gwiezdnych wojen (reż. George Lucas, 1999, 2002), czy powoływanych do istnienia całych światów, jak w Avatarze Jamesa Camerona (2009). Bez animacji nie byłoby gier video. Pojawia się ona w rozmaitych formach reklamy. W rozmaitych technikach realizuje się animowane videoklipy, obecne $\mathrm{w}$ świadomości odbiorców przede wszystkim dzięki pionierskim osiągnięciom Zbigniewa Rybczyńskiego (Grodź 2015, 267) oraz Steve’a Barrona, autora teledysków do piosenek Money for Nothing zespołu Dire Streits i Take on me grupy a-ha. Coraz częściej stanowi także element kina dokumentalnego, pozwalając ukazać stany bohatera i sytuacje, dla których trudno znaleźć ekwiwalent w realnym świecie. Twórcy popkultury i artyści doskonale zdają sobie sprawę, że „dzięki animacji możemy osiągnąć wszystko, co tylko sobie wyobrazimy, i stworzyć sztukę niemożliwości" (Wells 2009, 12).

Skoro definicja animacji i filmu animowanego nastręcza tylu trudności, to i jej próby systematyzacji pozostają niedoskonałe i zwykle niekompletne. Andrzej Kossakowski, na przykład, proponuje podział na animację dwuwymiarową i przestrzenną, który jest klarowny, lecz uwzględnia wyłącznie jeden aspekt filmu animowanego. Z przyczyn praktycznych często klasyfikuje się filmy animowane ze względu na metraż filmu, niekiedy na technikę, w jakiej zostały wykonane. Także w wypowiedziach twórców, miłośników i krytyków filmu animowanego pojawiają się próby podziału intuicyjnego, wyrastającego z artystycznej praktyki. Jeden z przedstawicieli młodego pokolenia polskiej animacji w rozmowie z Mariuszem Frukaczem podkreśla:

Uważamy, że przed rokiem 1989 nie było czegoś takiego jak animacja komercyjna, dlatego jest to na polskim rynku zjawisko nowe, do którego próbujemy się jakoś odnosić. (...) Podzieliliśmy animacje na cztery takie grupy. Pierwszą działkę stanowi to, co doskonale znamy, film autorski, animacja artystyczna. Trafia ona do wąskiej grupy odbiorców, często do elit, i ma małe szanse na zaistnienie pośród szerszej widowni, co związane jest z niewielkimi korzyściami finansowymi. Na drugim biegunie jest animacja czysto komercyjna, czyli np. obracający się kubeczek jogurtu w reklamie - coś, co cierpi z kolei na niski poziom artystyczny i brak smaku, ale 
ma ogromną widownię i przynosi profit. Pomiędzy tymi skrajnie biegunowymi podgrupami należy umieścić jeszcze dwie rubryki. Pierwsza z nich to grupa animacji całkowicie nieobecnych w Polsce, czyli animacji rozrywkowych (szeroka grupa odbiorców, wysoki poziom artystyczny, np. Trio z Belleville, Persepolis, Król Lew, Ratatuj). No i mamy jeszcze czwartą grupę, nazywaną przez nas po prostu tandetą (Frukacz 2008, 214-215).

Spojrzenie na film animowany jako na grupę utworów rozpostartych pomiędzy dwoma biegunami kina: komercyjnym i artystycznym, jest wprawdzie wysoce dyskusyjne, pozwala jednak dostrzec szerokie spectrum tej działalności filmowej, objąć filmy, w których przejawiają się ambicje artystyczne, poszukiwania formalne, a zarazem pozostające animacjami o charakterze komercyjnym, jak współczesne produkcje dla stacji telewizyjnych, które w ramach rynkowej logiki muszą przynieść zysk.

\section{Jeden epizod $\mathrm{z}$ długiej historii}

W historii kina animowanego niemal od początku rozrywka i zysk spotykały się ze sztuką. Niekiedy drogi twórców zbliżających się do jednego lub drugiego bieguna filmowej animacji rozchodziły się, przebiegały równolegle, choć w dużej odległości, ale bywały też momenty, zaskakująco częste, w których ścieżki te krzyżowały się. Trzeba jednak podkreślić, że animacja popularna nie zawsze była i jest otwarta na zmiany formalne, z rzadka miewa i miewała charakter subwersywny - jej twórcy nie poszukują nowych rozwiązań artystycznych, pozostając również niezwykle konserwatywni w sferze prezentowanych treści. Najdobitniejszą ilustrację tej tezy stanowią smutne losy Myszki Miki. Najsłynniejsza bodaj postać kina anonimowego wyrosła z uprzemysłowienia animacji, które bez wątpienia wpływało na estetykę kina animowanego, szczególnie w Stanach Zjednoczonych lat 30., gdzie skala tego procesu była największa. Industrializacja związana była ściśle z dominacją produkcji seryjnych, które gwarantowały wysokie i w miarę pewne dochody. Z czasem owa seryjność zaczęła ograniczać innowacyjność estetyczną i skłonność do eksperymentu, na co znacząco wpłynęła telewizyjna dystrybucja serialu. Myszka Miki w pierwszych odcinkach serii była skłonnym do psot, dość brutalnym łobuzem, animowanym odpowiednikiem chaplinowskiego trampa o złotym sercu. Współcześnie jest niezwykle uładzonym, grzecznym stworzeniem w pastelowych barwach, w zachowaniach którego dydaktyzm jest aż nazbyt czytelny. Niegdyś, gdy po raz pierwszy widzowie mogli usłyszeć ją w kinie, gdy pracowano nad niezwykłą płynnością jej ruchów, serial z udziałem Myszki można było uznać za nowatorski. Dziś zarówno w warstwie plastycznej, jak i treści nie wyróżnia się niczym na tle innych produkcji telewizyjnych.

Bodaj najciekawsze pole spotkania z pozoru odległych nurtów animacji stanowiły poszukiwania w sferze syntezy ruchu i dźwięku. Istotą każdego filmu, również animacji, jest współistnienie, powiązanie ruchomego obrazu i dźwięku. Ruch, jak wspomniałam, to istota kina w ogóle. Obraz w kinie 
animowanym, inaczej niż w aktorskim, niemal zawsze pozostaje w ścisłym związku z szeroko rozumianymi sztukami plastycznymi i tam należy szukać jego genezy. Trzecim ogniwem pozostaje dźwięk. Nie tylko muzyka i słowo, ale również (a czasem przede wszystkim) efekty akustyczne. Dopiero z syntezy tych trzech elementów - obrazu, ruchu i dźwięku - rodzi się film animowany.

Od początku istnienia animacji ${ }^{1}$, która rozwijała się równolegle do filmu fabularnego aktorskiego i dokumentalnego (za pierwszy film lalkowy uważa się Humpty Dumpty Circus Jamesa S. Blacktona z roku1898, pierwsza animacja rysunkowa, Wokół kabiny Emile Reynaud, pochodzi z roku 1894), twórcy marzyli, by połączyć film animowany z dźwiękiem. Słynne zdanie Irvinga Thalberga „There never was a silent film” (Vieira 2010, 90) odnosiło się do kina animowanego jak do żadnej innej dziedziny rodzącej się kinematografii. Wprawdzie większość filmów w okresie kina niemego przedstawiana była widzom przy akompaniamencie muzycznym, ale tylko w filmie animowanym zakładano rytm, który ściśle wiązał się z muzyką. Muzyce podporządkowano gagi, zachowania postaci, metamorfozy świata przedstawionego. Gdy tylko stało się więc możliwe użycie dźwięku w kinie, natychmiast sięgnęli po niego animatorzy. Jeszcze nim nakręcony został pierwszy pełnometrażowy aktorski film dźwiękowy, z dźwięku skorzystali bracia Fleischerowie w 12-odcinkowej serii Rysunkowe piosenki z klaunem Koko (1924-1927).

Droga do osiągnięcia pełnej synestezji okazała się jednak długa, choć już w realizowanych w końcu lat 20. kreskówkach usilnie poszukiwano sposobu na doskonałe sprzężenie obrazu z muzyką, czego przykładem są Silly Symphonis powstające od roku 1929, a wśród nich słynny Taniec szkieletów otwierający serię. Należy zaznaczyć, że to właśnie wówczas produkcja filmów animowanym stawała się stopniowo istotną gałęzią przemysłu kinematograficznego. Filmy animowane powstawały już nie tylko w domowym zaciszu animatorów. Funkcjonować zaczynały studia specjalizujące się w produkcji animacji jak Disneya Brothers Cartoon Studio ${ }^{2}$ (1923) czy powiązane z Paramountem Fleischer Studio (1921). Pod koniec lat 30. działały one już jak ogromne korporacje z charakterystycznym dla tego typu firm podziałem pracy i funkcji. Wzorem dla Disneya stał się gigant motoryzacyjny Forda. Po sukcesie Królewny Śnieżki Disney zatrudniał aż 1400 animatorów. Już wówczas, by połączenie muzyki i efektów dźwiękowych z obrazem było jak najdoskonalsze, pracownicy Disneya wysyłali do udźwiękowienia filmy ze znacznikami, pozwalającymi w odpowiednich miejscach umieścić właściwe fragmenty muzyczne. Animacja, inaczej niż dwie inne dziedziny kina, bez trudu obchodziła się natomiast bez słów, pozostając

\footnotetext{
Historię tych poszukiwań relacjonuję na podstawie: Krótka historia animacji filmowej 1997-1998, Katzenberg 2006, Sitkiewicz 2009.

2 W 1923 r. bracia Roy i Walt Disney założyli niewielkie studio pod nazwą Disney Brothers Cartoon Studio, które ewoluowało w ogromną korporację medialną The Walt Disney Company. Jej częścią jest obecnie kilkanaście studiów filmowych.
} 
ważnym narzędziem komunikowania i adaptacji kulturowej rzeszy nieanglojęzycznych emigrantów w Ameryce. Muzyka była tym elementem, który pozwalał na stworzenie pełnego dzieła. Na marginesie warto odnotować, że ten specyficzny stosunek animatorów do dźwięku sprawił, że - inaczej niż w filmie aktorskim - w sztuce tej nie można mówić o regresie środków wyrazu, który dotknął aktorskie kino wczesnodźwiękowe.

Animacja zawieszona była pomiędzy kinem jako rozrywką a kinem jako sztuką, pomiędzy popkulturowymi opowieściami głównie dla dzieci a ambicjami stworzenia ruchomego malarstwa idealnie zintegrowanego z muzyką. Disney przez lata sprawnie łączył aspiracje artystyczne z chęcią zysku. Odczuwał potrzebę wyniesienia animacji do rangi sztuki. Zwieńczeniem tych prób był pełnometrażowy film jego wytwórni Fantazja (1940) (Majewski 2006). Dziś rozpatrujemy często tę próbę połączenia muzyki klasycznej z filmem animowanych jako swego rodzaju trawestację, która zbliżała muzykę klasyczną do rozrywki, czyniła ją bardziej „strawną” dla szerokiej publiczności. Możemy się jednak pokusić o hipotezę przeciwną: stworzenie animowanej fantazji, inspirowanej luźną konstrukcją tej formy muzycznej, mogło równie dobrze służyć podniesieniu prestiżu filmu animowanego, który w powszechnym odbiorze stawał się wówczas tanim i zabawnym dodatkiem do prawdziwego kina. Oglądamy więc w Fantazji mnóstwo obrazów bezpośrednio nawiązujących do malarstwa, np. ekspresjonistów Noldego, Muncha, Ensora, w ostatnich scenach do dzieł Caspara Davida Friedricha. Słuchamy Bacha, Czajkowskiego, Strawińskiego, Musorgskiego, Schuberta, Dukasa. Dostrzegamy ślady fascynacji kinem, przede wszystkim niemieckim ekspresjonizmem.

Fantazja miała być spełnieniem marzeń o synkretyzmie, a dla wielu krytyków i odbiorców stała się ucieleśnieniem nowoczesnego kiczu, „szyderczego spełnienia Wagnerowskich marzeń o całościowym dziele sztuki" (Adorno, Horkheimer 2010). Powstała wedle nich karykatura dzieła, które miało być wyrazem absolutnej idei Gesamtkunstwerk. Trzeba przyznać, że Fantazja jest utworem bardzo nierównym, gdy idzie o wartości artystyczne, ale stanowi bardzo ciekawy przykład popkultury, która wchłania wysoką sztukę i myśl, stanowi wyraz poszukiwań formalnych, artystycznych. Disney próbował w niej wykorzystać te elementy, które dla ucieleśnienia idei o synkretyzmie wydawały mu się najbardziej użyteczne, przede wszystkim możliwość perfekcyjnej synchronizacji obrazu i dźwięku w filmie animowanym, a jednocześnie zredukować fabułę zasadzającą się zwykle w jego wcześniejszych krótkich filmach na serii gagów. Niekiedy, w bardzo jednak krótkich fragmentach, twórcy Fantazji próbują w ogóle uciec od animacji przedstawiającej. Z ambicji Disneya, by umieścić w filmie fragmenty abstrakcyjne, zrodził się pomysł zatrudnienia do realizacji filmu Oscara Fischingera, znanego animatora awangardowego (autora, między innymi, słynnej Kompozycji w błękicie z 1935 r. i Poematu optycznego z 1937 roku). Disney zlecił mu przygotowanie wizualnej koncepcji 
części filmu, w której zamierzał wykorzystać Toccatę i Fugę d-moll Bacha. Produkcyjna machina Wytwórni Disneya tak jednak zniekształcała pomysły Fischingera, że w końcu doszło do zerwania współpracy, a kilka lat później (1947 roku) ten awangardowy twórca zrealizował Motion Picture no. 1 do allegra z III Koncertu brandenburskiego Bacha. Ślady koncepcji Fischingera odnajdujemy jednak w środkowej części filmu, w którym pojawia się scena występu soundtracku, czyli fluorescencyjnego wykresu, prezentującego możliwości poszczególnych instrumentów muzycznych.

Dzieło animatorów z Wytwórni Disneya prezentuje możliwości kina animowanego, zawiera niejako w sobie dwa wspomniane bieguny filmu animowanego, rozmaite warianty - od popkulturowej opowieści o Myszce Miki, po abstrakcje w duchu Fischingera. Jako szczególny konglomerat sposobów myślenia o animacji i stylów kina animowanego pokazuje pewną znamienną, wyróżniającą cechę filmu animowanego, którego estetyki rodzą się na styku istniejących sztuk, tworząc z gotowych cegiełek nowy język, odrębny względem źródeł, a jednak pozostający z nimi w nierozerwalnym związku.

Przywołane przykłady pokazują dobitnie, że nie możemy mówić o jednej estetyce filmu animowanego, skoro w jego obrębie realizowane były i nadal są awangardowe dzieła niekiedy zupełnie pozbawione anegdoty, jak i utwory, o których istocie stanowi ludzka potrzeba opowiadania. Możemy jednak wskazać pewne cechy decydujące o odrębności filmu animowanego. Podsumowując, jest to dziedzina filmu przynależna kinu fikcjonalnemu, której esencję stanowi kreacyjność oraz minimalna referencjalność. Ponadto, jak żadną inną formę filmową, cechują ją dążność do syntezy obrazu i dźwięku i do artystycznego synkretyzmu.

\section{Młody widz przed ekranami}

Plastyka się starzeje - stwierdza Agnieszka Sadurska. Filmy dla dzieci mają powstać tu i teraz. Kiedyś wystarczył Reksio i Bolek i Lolek. Dzisiaj sposób narracji, design, zmieniają się szybko, podobnie jak przyśpiesza ludzka percepcja. Animacja dla dzieci powinna spełniać również funkcję użytkową. Chcąc skutecznie porozumieć się z dzieckiem, trzeba używać współczesnych środków wyrazu, znanych dziecku, które ogląda animację głównie na obowiązujących, telewizyjnych kanałach dziecięcych (Armata 2014, 192).

Polski producent filmów animowanych, Włodzimierz Matuszewski, dostrzega kulturotwórczą rolę animacji telewizyjnej:

Największym nośnikiem wartości jest bohater. Kiedy oglądam seriale takie, jak wspomniany Świat małej księżniczki, widzę, że funkcja edukacyjna jest przykryta przedstawieniem świata zbudowanego na codzienności. Dzieci w tej chwili szybciej dojrzewają intelektualnie. Mają większy kontakt z mediami, z Internetem, z komórką, z mobilnymi urządzeniami, na których oglądają wszystko. Także to, co dorośli (Armata 2014, 215). 
Choć z żalem myślimy, że dzisiejszy kilkulatek nie czeka z wypiekami na twarzy na kolejny odcinek Reksia, Pszczółki Mai czy Smerfów, to warto przyjrzeć się współczesnym produkcjom dla dzieci, temu, co oglądają najchętniej i co kształtuje ich kompetencje społeczne i audiowizualne. Skłania do tego również fakt, że serial animowany dla dzieci - najchętniej oglądany typ animacji - staje się dziś głównym obszarem poszukiwań artystycznych i przekraczania obyczajowego tabu w obrębie animacji popularnej. O ile większość filmów dla dorosłych prezentowana jest wyłącznie na festiwalach i w pewnym stopniu w internecie, to animacja dziecięca trafia do potencjalnych odbiorców przez znacznie więcej szerokich kanałów dystrybucyjnych. Dzieci stanowią dziś jedyną grupę odbiorców, która ma stały kontakt z filmem animowanym.

Wciąż istotnym miejscem dystrybucji filmu animowanego, szczególnie pełnometrażowego, pozostaje kino. Repertuary kin, np. w okresie wakacyjnym, zdominowane bywają przez pełnometrażowe filmy animowane. Jak podaje Polski Instytut Sztuki Filmowej, pośród dziesięciu najchętniej oglądanych w weekend 29-31 stycznia 2016 roku w Polsce filmów kinowych znajdowały się aż trzy filmy animowane, wszystkie przeznaczone dla widza dziecięcego (Alvin i wiewiórki. Wielka wyprawa - 116149 widzów, Odlotowa przygoda - 34922 widzów, Barbie: tajne agentki - 22053 widzów zajmujące w box-office odpowiednio 3, 5, 10 miejsce) (www.pisf.pl/rynek-filmowy/box-office). Kinowe produkcje dla dzieci stanowią ogromną część współczesnego rynku kinematograficznego i formatują przyszłego widza kształtują jego gust i „horyzont oczekiwań”, uczą odczytywania konwencji. $\mathrm{W}$ warstwie formalnej filmy te pozostaje od lat niezwykle zachowawcze.

W animowanych pełnometrażowych filmach dla dzieci zaobserwować można zjawisko estetycznej konwergencji, której źródła tkwią z pewnością w nieuniknionym i zapoczątkowanym przed dziesięcioleciami uprzemysłowieniu produkcji. Animacja komputerowa, stosunkowo tania i szybka w produkcji, króluje dziś niepodzielnie na ekranach naszych kin. Zaludniają je postaci o podobnych rysach, ruchach i kształtach. I nawet tak ciekawe propozycje, jak film Disneya i Pixara Inside out ( $W$ głowie się nie mieści, 2015) Pete'a Doctera, próbujące ukazać emocje dziecka, toną w pastelowej, sztampowej oprawie plastycznej. Recenzentka „Tygodnia Powszechnego” pisała o Inside Out: „Film Pete’a Doctera to bajka terapeutyczna, tłumacząca małym i dużym, jak działają uczucia, fantazje i wspomnienia. Gdyby nie komputerowa estetyka, byłaby arcydziełem" (Piotrowska, www.tygodnikpowszechny.pl/byly-sobie-emocje-29089). Jak w wielu innych filmach dla dzieci w Inside out oglądamy bohaterów o nieproporcjonalnie dużych głowach, ogromnych tęczowych oczach i w jaskrawych ubraniach. Film ten jednak wyróżnia się myśleniem abstrakcyjnym i niestereotypowym potraktowaniem dziecięcej wyobraźni, podczas gdy większość animowanych produkcji kinowych dla dzieci również w sposobie portretowania dziecięcych bohaterów i ich środowiska jest bliźniaczo do siebie podobna. 
Drugi spośród głównych kanałów dystrybucyjnych animacji dziecięcej telewizja - oferuje liczne kanały uwzględniające, ale i generujące potrzeby młodych widzów. Wciąż rośnie liczba stacji dla dzieci i w związku z tym coraz bardziej widoczna staje się ich specjalizacja. Konkurencja zmusza nadawców do precyzyjniejszego definiowania obrazu potencjalnego odbiorcy. Są wśród nich stacje kierowane do uczniów pierwszych klas szkoły podstawowejjak Cartoon Network, dzieci w wieku przedszkolnym (np. MiniMini+), ale również dla widzów jeszcze młodszych. Stacja Duck TV adresowana jest do dzieci w wieku od 6 do 36 miesięcy i reklamowana jako telewizja dla absolutnie początkujących („Television for absolute beginners”). Do najchętniej oglądanych kanałów dla dzieci należą ogólnodostępny TVP ABC oraz Nickelodeon i Cartoon Network. Te trzy stacje znajdują się pośród 25 najczęściej oglądanych stacji w Polsce (dane ze stycznia 2016, www. wirtualnemedia.pl/artykul/tvp-info-i-tvn24-na-czele-w-styczniu-fokus-tv-z-najwiekszym-wzrostem-top-25-stacji-tematycznych). Wspomniane kanały od dłuższego czasu znajdują się także na czele rankingów oglądalności w grupie wiekowej 4-12 lat (dane z października 2015: www.wirtualnemedia.pl/artykul/nickelodeon-na-czele-stacji-dzieciecych-bbc-cbeebies-z-najwiekszym-wzrostem).

Dane telemetryczne potwierdzają, że wpływ telewizji na wyobraźnię dzieci nie słabnie. Właściciele domów medialnych i producenci doskonale zdają sobie sprawę, że widzowie dziecięcy stanowią olbrzymi potencjał do zagospodarowania. Większość prezentowanych w tych stacjach produkcji to dawne polskie i zagraniczne animacje (w niewielkim stopniu również produkcje nowsze, np. Bajki i baśnie polskie, produkowane przez Telewizyjne Studio Filmów Animowanych w Poznaniu w latach 2002-2005) w przypadku TVP ABC oraz seriale tworzone specjalnie dla poszczególnych stacji, które identyfikowane są z konkretnymi kanałami. Ciekawych przykładów dostarcza niezwykle popularna, choć o ograniczonym zasięgu ${ }^{3}$, stacja Cartoon Network, funkcjonująca na polskim rynku medialnym od 1998 roku. Obecnie nadaje ona trzy typy seriali: odcinkowe animacje o ustalonej od lat renomie jak The Looney Tunes Show (w ramach tego pasma ogladać można kontynuacje seriali o przygodach Królika Bugsa czy Kaczora Duffy'ego ${ }^{4}$ ), seriale ściśle powiązane z ogromną machiną marketingową, promujące nowe zabawki i gry (np. Lego Ninjago: Masters of Spinjitzu, duński serial inspirowany kulturą japońską) oraz produkcje oryginalne, poszukujące nowych rozwiązań formalnych i proponujące odległe od stereotypowej „bajki” animowanej spojrzenie na świat. Do tej ostatniej grupy należą seriale omówione poniżej.

\footnotetext{
Cartoon Network dostępne jest na wybranych platformach cyfrowych (np. nc+, Cyfrowy Polsat) oraz w sieciach kablowych. Odbiór stacji związany jest ponoszeniem dodatkowych kosztów, przekraczających minimalną opłatę za pakiety oferowane przez poszczególnych operatorów.

4 Bugs i Duffy to jedni z najstarszych bohaterów filmu animowanego. Obie postaci stworzone zostały w drugiej połowie lat 30. w wytwórni Warner Brothers.
} 
Na szczególną uwagę, w moim przekonaniu, zasługuje grupa filmów, których autorzy operują abstrakcją i absurdalnym humorem, np. Wujcio Dobra Rada Petera Browngardta (prod. Cartoon Network Studios, 2013), Pora na przygode Pendletona Warda, (prod. Frederator Studios i Cartoon Network Studios, 2010) dwukrotnie nagrodzona Emmy Award w kategorii najlepsze indywidualne osiągnięcie $\mathrm{w}$ animacji. Te nagrody świadczą o wysokim poziomie artystycznym seriali. Oba to animacje rysunkowe, których siła tkwi w koncepcji plastycznej ściśle zespolonej z nowatorską konstrukcją postaci: tytułowego Wujcia, który miast pomagać dzieciom, wikła je zwykle w jeszcze większe problemy, oraz człowieka Finna i psa Jake’a z Pory na przygodę, wędrujących po przedziwnej Krainie Ooo, która wyłoniła się na ziemi po apokaliptycznej Wielkiej Wojnie Grzybów. Ciekawym zabiegiem $\mathrm{w}$ Porze na przygode jest nielinearne prowadzenie narracji, rozwijanie kolejnych wątków na podstawie elementów drugoplanowych z poprzednich epizodów. To, co łączy oba seriale i wiele innych produkcji emitowanych w najważniejszych kanałach dla dzieci, to ich intertekstualny charakter. Opowieści w nich snute uwikłane są w gęstą sieć odwołań do utrwalonych w tradycji bajkowej i baśniowej zdarzeń (np. ratowanie królewny, walka ze złym smokiem) i równocześnie do współczesnej kultury popularnej, z którą dzieci kontaktują się mimochodem.

Dydaktyzm tych seriali jest nieoczywisty, jak nieoczywiste są odniesienia do rzeczywistości. W Wujciu Dobra Rada dziecięcy bohaterowie istnieją w rzeczywistości o dużym stopniu referencjalności, ale wraz z przybyciem Wujcia owa referencjalność zanika, a świat przedstawiony przekształca się w przestrzeń pełną odnóg, tajemnych przejść i zakamarków czasu, o nikłym związku z fizykalną rzeczywistością. Problemy dzieci pozostają jednak niezmienne: brak akceptacji, odrzucenie, trudne relacje z rodzicami, kłopoty z komunikowaniem się z drugim człowiekiem. Co ciekawe, Wujcio został wyposażony w cechę, która dla małego widza ma właściwości kompensujące i jest źródłem humoru: choć zawsze kierują nim dobre intencje, jego wiedza o świecie jest znacznie ograniczona, dlatego postanawia przelizać słoik z masłem orzechowym na wylot i czyni szczegółowe obliczenia, ilu Wujciów jest potrzebnych do wkręcenia jednej żarówki. Inne postaci serialu charakteryzowane są za pomocą kilku bardzo wyrazistych cech. Ulegają jednak przemianom w ramach poszczególnych epizodów. Do kompanii Wujcia należy Stefek Pizza, cierpiący na narcyzm kawałek pizzy w okularach przeciwsłonecznych, Gustaw - dinozaur, najsilniejszy z całej drużyny, Torba-Borba, oferująca nieprzebrane bogactwa, mówiąca saszetka zawieszona na pasie Wujcia i wreszcie - Wielka Realistyczna Tygrysica. Stanowi ona jedyny wycinankowy element $w$ tej animacji. Jej nominalny realizm jest konsekwencją faktu, że została wycięta $\mathrm{z}$ fotografii. Twórcy serialu wprowadzają w ten sposób młodych widzów w obecną dziś we wszystkich mediach audiowizualnych grę pomiędzy elementem fikcjonalnym i niefikcjonalnym. 


\section{Na granicy światów - Niesamowity świat Gumballa}

Zaskakujące rozwiązania przyjął również Benjamin Bocquelet w serialu Niesamowity świat Gumballa (prod. Cartoon Network Studios, 2011). Od premiery w 2011 roku seria zdobyła 15 prestiżowych nagród, wśród nich m.in.: BAFTA, trzy Kidscreen Awards, dwie British Animation Awards, Annie, Prix Jeunesse Award i Cristal Award na festiwalu w Annecy. Jego twórcy operują animacją kombinowaną, łączącą fotografię z rysunkiem i wycinanką. Wykorzystują techniki dwu- i trójwymiarowe. Animowani bohaterowie, człowiek-kot Gumball Watterson i jego brat Darwin, rybka akwariowa z nogami i rękoma, pojawiają się więc często na tle przestrzeni sfotografowanej. Zabieg łączenia realizmu fotograficznego z kreacyjnością animacji nie dotyczy wyłącznie przestrzeni. Obejmuje on także sposób budowania przedstawionej rzeczywistości, przede wszystkim konstruowania bohaterów. Część z nich to typowe dla bajki antropomorfizowane zwierzęta. Główne postaci przyjaźnią się jednak z bananem (Banan Joe), balonem (Alan), kaktusem (Carmen) czy tostem (Anton). Zwykle własności przedmiotów, roślin i zwierząt obrazują jednocześnie najważniejsze cechy bohaterów, choć niekiedy zestawienia te nie są umotywowane w żaden sposób. Status postaci jest zróżnicowany: niektóre z nich to kukiełki, inne zostały narysowane, jeszcze inne wycięte $\mathrm{z}$ fotografii.

Na plastyczne wyrafinowanie i nietypowy sposób wpisywania w strukturę serialu podwójnego wirtualnego odbiorcy zwracał uwagę Ken Tucker, recenzent „Entertaiment Weekly”:

Warstwa wizualna może dotykać/poruszać młodych widzów, ale jednocześnie wyrafinowanie postaci i nawiązania do ostatnich dekad w kulturze popularnej trafią również do odbiorców starszych (Tucker 2012).

Twórca Niesamowitego świata Gumballa należy do pokolenia lat 80. wychowanego na estetyce kina tamtego czasu. Jako bezpośrednie źródło inspiracji dla swego serialu wskazuje film Gremliny rozrabiaja (reż. Joe Dante, 1984) i Powrót do przyszłości (reż. Robert Zemeckis, 1985). Dzięki tym nawiązaniom rozszerza grono potencjalnych odbiorców o rodziców urodzonych na przełomie lat 70. i 80. „Podwójne kodowanie”, kierowanie przekazu jednocześnie do dwóch różnych grup odbiorczych, stało się dziś niezbywalnym elementem produkcji dla dzieci. Zwykle jednak podział elementów w strukturze utworu ze względu na projektowanych widzów dzieci i dorosłych - był czytelny, dziś ulega wyraźnemu zatarciu.

$\mathrm{Na}$ formalną stronę animacji oraz na znaczeniową istotę serialu zwracał uwagę recenzent „Variety”, Brian Lowry:

Przedstawiający źle wychowane dzieci i zmęczonych rodziców, serial o zabawnej warstwie wizualnej - $\mathrm{z}$ animowanymi postaciami zderzonymi $\mathrm{z}$ fotorealizmem teł (...) - to przede wszystkim bardzo mądra opowieść o chaosie codzienności (Lowry 2011). 
Niesamowity świat Gumballa cechuje bowiem nie tylko formalna odwaga, której próżno szukać dziś w animacjach kinowych dla dzieci, ale również wciąż rzadka wrażliwość na kulturowe przemiany współczesnego świata. Rodzina Gumballa mieszka w niewielkim domu na przedmieściach miasta Elmore. Wattersonowie mają troje dzieci: najmłodszą, słodką i bystrą Anais, dwóch nierozłącznych synów - Gumballa i Darwina. Głową rodu jest bez wątpienia mama Nicole, choć łatwo ulega emocjom, dla rodziny skłonna jest poświęcić wszystko. Ona podejmuje w domu najważniejsze decyzje. Ojciec spędza większość czasu przed telewizorem, nie pracuje. Jest nieporadny i lekkomyślny. Mimo wielu negatywnych cech (również zewnętrznych - jest wielkim, grubym, różowym królikiem), w jego postaci na plan pierwszy wybija się ciepło oraz miłość do dzieci i żony. Serial pokazuje więc w sposób przejaskrawiony odwrócenie do niedawna standardowych ról społecznych $\mathrm{w}$ rodzinie. $\mathrm{W}$ hiperbolizującej formule zaprezentowana została również opresywna szkoła. Podobnie jak we wcześniej przywołanych serialach, w Niesamowitym świecie Gumballa nie ma miejsca na sielski obraz świata i społecznych relacji oraz na prosty dydaktyzm. Główny bohater jest postacią zniuansowaną, ułatwiającą identyfikację, ale i dostarczającą widzom satysfakcji, ponieważ większość z nich góruje nad Gumballem wiedzą i umiejętnościami. Mały Watterson bywa lekkomyślny, samolubny i po prostu głupi, ale również czuły, empatyczny i dobry. Nie uczy się na własnych błędach, ale sposób organizacji świata przedstawionego, konstrukcja fabuły dostarczają młodym widzom informacji na temat konsekwencji podejmowania określonych działań. Wiemy, że bohater jest nierozsądny, więc jego postępowanie musi przynosić przykre skutki. Paradoksalnie więc, choć Gumball nie świeci przykładem, jego decyzje i ich następstwa niosą w sobie pewien ładunek dydaktyzmu. Niesamowity świat Gumballa wyróżnia także sposób ukazywania emocji i radzenia sobie z nimi. Uczucia to główny temat serialu, przy czym nie zawsze są to emocje pozytywne. Poszukiwanie ich ekwiwalentu obrazowego w postaci deformacji, a nawet destrukcji bohaterów, może stanowić przyczynek dla rozumienia emocjonalności drugiego człowieka.

Kino animowane wciąż odnawia swój język. Szuka inspiracji w najnowszych trendach artystycznych, jak sejsmograf zapisuje drgania we współczesnej kulturze audiowizualnej, a jednocześnie trafia - przede wszystkim w wersji dla młodego widza - do szerokiego grona odbiorców. Jak pokazują jednak niektóre najnowsze seriale dla dzieci, masowość nie wyklucza artystycznej wartości, choć kierunek poszukiwań współczesnych twórców jest bardzo odległy od tego, jaki wytyczała Fantazja. Ale też animacja dziś nie musi walczyć o swą autonomię. Jest pełnoprawną dziedziną sztuki filmowej i przemysłu kinematograficznego, cenioną przez odbiorców, choć wciąż niedocenianą przez teoretyków, dziedziną o niebywałej sile oddziaływania na przyszłe pokolenia widzów. 


\section{Bibliografia:}

Adorno Theodor, Horkheimer Max, 2010, Dialektyka Oświecenia, Łukasiewicz M. (przeł.), Warszawa.

Armata Jerzy, 2014, Polski film dla dzieci i młodzieży, Warszawa.

Balázs Béla, 1957, Wybór pism, Jung K., Porges R. (przeł.), Jackiewicz A. (oprac.), Warszawa.

Cholodenko Alan, 1997-1998, Usidlanie klatek w animacji, Rutkowska T. (przeł.), „Kwartalnik Filmowy”, nr 19-20.

Denslow Phillip Kelly, 2011, What is animation and who needs to know? An essay on definition, w: A Reader in Animation Studies, Pilling J. (red.), Indiana University Press.

Elsaesser Thomas, 2001, Kino cyfrowe: nośnik, wydarzenie, czas, Wilczyńska A., Majewska E. (przeł.), „Kwartalnik Filmowy”, nr 35-36.

Frukacz Mariusz, 2008, 24 klatki na sekundę. Rozmowy o animacji, Kraków.

Giżycki Marcin, 2000, Nie tylko Disney. Rzecz o filmie animowanym, Warszawa.

Grodź Iwona, 2015, Synergia sztuki i nauki w twórczości Zbigniewa Rybczyńskiego, Warszawa.

Irzykowski Karol, 1982, X Muza oraz Pomniejsze pisma, Kraków.

Katzenberg Jeffrey, 2006, Sztuka animacji: od ołówka do piksela: historia filmu animowanego, Romkowska E., Kołodyński A. (przeł.), Warszawa.

Krótka historia animacji filmowej, 1997-1998, Rutkowska T. (oprac.), „Kwartalnik Filmowy”, nr 19-20.

Lowry Brian, 2011, Cartoon Net Charms With Clever Import Gumball, „Variety”, May 4.

Majewski Tomasz, 2006, Od Feature Concert do Gesamtkunstwerk: »Fantazja« Walta Disneya, w: Kino amerykańskie: dzieła, Durys E., Klejs K. (red.), Kraków.

Piotrowska Anita, Były sobie emocje, https://www.tygodnikpowszechny.pl/bylysobie-emocje-29089

Sitkiewicz Paweł, 2009, Małe wielkie kino: film animowany od narodzin do końca okresu klasycznego, Gdańsk.

Tucker Ken, 2012, Wildly imaginative, with tantrums and giggles, „Entertaiment Weekly". August 12.

Vieira Mark, 2010, Irving Thalberg: Boy Wonder to Producer Prince, Berkeley.

Wellins Mike, 2015, Myśleć animacja. Podręcznik dla filmowców,

Wojnach A. (przeł.), Warszawa.

Wells Paul, 2009, Animacja, Garbiński A. (przeł.), Warszawa.

Wójcik Jerzy, 1997-1998, Kilka uwag o animacji kinematograficznej (inspirowanych twórczościa reżysera Henryka Ryszki), „Kwartalnik Filmowy”, nr 19-20. 


\section{O Autorce:}

Katarzyna Mąka-Malatyńska - wykładowca w Katedrze Filmu, Telewizji i Nowych Mediów UAM w Poznaniu oraz w Państwowej Wyższej Szkoły Filmowej, Telewizyjnej i Teatralnej w Łodzi. Prowadzi zajęcia z zakresu historii kina dokumentalnego i animowanego oraz analizy filmu. Jest autorką kilkudziesięciu artykułów naukowych i książek: Krall i filmowcy, Poznań 2006, Europa Europa, Poznań 2007, Ludzie polskiego kina. Agnieszka Holland, Warszawa 2009, Widok z tej strony. Przedstawienia Holocaustu $w$ polskim filmie, Poznań 2012. Współpracuje z bazą internetową filmpolski.pl. 